\title{
Be Fit Bye Fat Sebagai Metode Peningkatan Derajat Kebugaran Jasmani Pegawai Pertamina MOR IV Semarang
}

Fajar Awang Irawan $^{a *}$, Hadi $^{b}$, Syahru Romadhonic, Dhias Fajar Widya Permana ${ }^{\mathrm{d}}$, Tafriyadhur Risa Billah ${ }^{\mathrm{e}}$

abcdeUniversitas Negeri Semarang, Indonesia

Correspondence: fajarawang@mail.unnes.ac.id

Received: 15 Jan 2021 Accepted: 26 Apr 2021 Published: 30 Apr 2021

\begin{abstract}
The purpose of this study was to find out the degree of physical fitness and increase knowledge about the management of physical activity and healthy diet through methods to reduce obesity and overweight rates of Pertamina MOR IV Semarang employees. The method of implementation of this research is Pretest posttest experiment. The total participants were 44 Pertamina MOR IV Semarang internal employees and willing to be participants in this research was shown by completing the willingness sheet to be a participant. The instruments used are a measurement of body mass index (BMI) and physical fitness and exercise assistance. The results of this study overview found that employees experienced an increase of 41 employees $(93.18 \%)$ while that did not increase by 3 Employees $(6.82 \%)$. the results showed that there was an increase in the percentage rate of physical fitness degree and a significant increase in strength levels compared to the decrease through the program "BE FIT BYE FAT" against Pertamina MOR IV Semarang employees
\end{abstract}

Keywords: obesity; physical activity; physical fitness.

\begin{abstract}
Abstrak
Tujuan dari penelitian ini adalah untuk mengetahui derajat kebugaran jasmani dan meningkatkan pengetahuan mengenai pengelolaan aktivitas fisik berolahraga dan pola makan sehat melalui metode be fit bye fat guna menurunkan angka obesitas dan overweight para pegawai Pertamina MOR IV Semarang. Metode pelaksanaan penelitian ini berbentuk pretest posttest experiment. Total partisipan adalah 44 orang pegawai internal Pertamina MOR IV Semarang dan bersedia menjadi partisipan dalam penelitian ini ditunjukkan dengan melengkapi lembar kesediaan menjadi partisipan. Treatment berupa progam latihan olahraga cardio, weight training, dan core stability. Instrumen yang digunakan adalah pengukuran indeks masa tubuh (IMT) dan kebugaran jasmani dan pendampingan latihan. Hasil dari gambaran umum penelitian ini ditemukan bahwa pegawai yang mengalami kenaikan berat badan sejumlah 41 pegawai (93,18 \%) sedangkan yang tidak mengalami peningkatan sejumlah 3 pegawai (6,82\%). Hasil penelitian menunjukkan bahwa terdapat kenaikan tingkat persentase derajat kebugaran jasmani dan kenaikan tingkat kekuatan yang signifikan di bandingkan penurunannya melalui progam "Be Fit Bye Fat' terhadap para pegawai pertamina MOR IV Semarang.
\end{abstract}

Kata kunci: aktivitas fisik; obesitas; kebugaran jasmani.

\section{Pendahuluan}

Olahraga merupakan aktivitas fisik yang baik bagi pemeliharaan kesehatan tubuh, membantu merangsang otot-otot dan bagian tubuh lainnya untuk memaksimalkan fungsi dalam bergerak, utamanya jika dilakukan secara berkala dan rutin. Dengan berolahraga menjadikan tubuh sehat dan 
bugar. Kesehatan sangat penting bagi manusia, karena tanpa kesehatan yang baik, setiap manusia akan sulit dalam melaksanakan aktivitasnya sehari-hari. Salah satu cara agar kesehatan tetap terjaga dengan baik adalah melalui olahraga (Prasetyo, 2015). Berolahraga artinya melakukan gerak badan seperti mesin yang jika tidak digunakan atau di gerakkan dalam jangka waktu lama perlahan-lahan bagiannya akan rusak karena tidak terlatih untuk terus bergerak dan bekerja, tubuh pun akan bermasalah dan tidak sehat jika kurang gerak (Pane, 2015). Mappaompo (2010) meyebutkan bahwa dengan berolahraga, metabolisme tubuh akan optimal dan otak sebagai pusat saraf akan bekerja menjadi lebih baik, melatih otot-otot sehingga tidak kaku dan peredaran darah juga sirkulasi oksigen dalam tubuh menjadi lancar. Seperti yang dijabarkan oleh Dodik (2015) bahwa berolahraga dalam waktu yang singkat asal rutin akan lebih baik karena akan lebih membantu mencapai tujuan kebugaran seperti ingin mengikuti perlombaan olahraga atau menurunkan berat badan.

Selain itu olahraga juga merupakan salah satu komponen utama gaya hidup sehat bersamaan dengan pola makan sehat dan penghindaran zat lain yang berbahaya bagi kesehatan. Metabolisme merupakan rangkaian proses kimiawi yang terjadi dalam sel-sel tubuh untuk mengubah zat gizi menjadi energi (Kusmawati, Lufthansa, Sari, \& Windriyani, 2019). Energi inilah yang membuat tubuh dapat menjalankan fungsi-fungsi dasarnya untuk bertahan hidup. Semakin banyak dan berat aktivitas fisik, semakin besar energi yang dihabiskan (jumlah kalori yang terbakar) (Indonesia Sport Nutritionist Association, 2018). Sementara jika jarang beraktivitas fisik, energi berlebih akan menumpuk dalam bentuk timbunan lemak. Menurut Nurcahyo (2011) melalui aktivitas jasmani yang dilakukan, anak akan mendapatkan banyak pengalaman gerak, kebugaran jasmani, mengenal jati diri dan lingkungannya. Selain itu melalui gerak atau aktivitas jasmani juga dapat memberikan manfaat lain, yaitu untuk mencegah terjadinya kegemukan (obesitas). Menurut Suyaputra \& Nadhiroh (2012) terdapat perbedaan yang bermakna pula pada tingkat aktivitas fisik seseorang, dimana sebagian pemilik obesitas hanya memiliki aktivitas ringan, sedangkan pemilik obesitas memiliki aktivitas sedang. Perlu upaya untuk mencegah obesitas dengan cara mengurangi faktor risiko, diantaranya pola makan sehat dan aktivitas fisik yang cukup. Kementerian Kesehatan RI (2018) juga menyebutkan bahwasannya penyebab permasalahan pada kesehatan terutama pada berat badan adalah di antaranya penyakit kronis/menahun, gejala penyakitnya tidak khas, fungsi organ yang menurun, sering disertai masalah nutrisi. Hal itu selaras dengan Nursalam \& Fallis (2013) karena alasan gaya hidup yang tidak seimbang dengan aktivitas olahraga akan menimbulkan kondisi status gizi dan kondisi fisik yang tidak stabil. Berdasarkan laporan dan fakta di lapangan Wilayah MOR IV Semarang. Sudargo, et al. (2014) menyebutkan banyak para pegawai yang mengalami masalah berat badan yaitu obesitas sehingga mempengaruhi tingkat kebugaran jasmani mereka. Widiantini \& Tafal (2014) menyebutkan hal ini mengakibatkan efek produktivitas kerja mengalami penurunan kinerja dalam beberapa tahun terakhir karena kurangnya pemahaman dan kesadaran akan pentingnya berolahraga dan pola makan hidup sehat menyebabkan menurunnya kemampuan seseorang disertai kelelahan dan penurunan fungsi fisiologis seseorang yang juga merefleksikan kinerja Pertamina. Oleh karena itu peneliti akan memberikan sebuah rekomendasi dalam bentuk metode atau suatu formula untuk mengatasi masalah tersebut. Tujuan dari penelitian ini adalah untuk meningkatkan dan memperbaiki kembali SDM pegawai untuk menunjang peforma kebugaran jasmani para pegawai Pertamina Wilayah MOR IV Semarang.

Penelitian terdahulu menyebutkan bahwa jenis kelamin, tingkat pendidikan, riwayat keturunan, aktivitas fisik, dan intake kalori berhubungan dengan kejadian obesitas sentral pada usia dewasa berbanding terbalik dengan tingkat pengetahuan, jenis pekerjaan, status merokok, dan status kawin (Puspitasari, 2018). Pendapat lain menyebutkan bahwa terdapat korelasi pola makan terhadap obesitas di kalangan usia dewasa (Ade Chintya Nirmala Dewi, 2013). Retnaningrum \& Dieny (2015) juga menyebutkan bahwa pola makan tidak seimbang dengan kualitas diet yang digambarkan melalui asupan makanan yang tidak sesuai dengan rekomendasi, sedangkan aktivitas fisik (pengeluaran energi) sangat minimal. Menurut Alfianto, et al (2016) obesitas akan meningkat seiring keluaran energi tidak seimbang dengan asupan energi sehingga terjadi masalah pada metabolisme dan merupakan penyebab 
utama obesitas. Christina \& Sartika (2011) juga menyebutkan makanan_dan minuman yang dapat diambil sesukanya menyebabkan tidak terkontrolnya asupan makan pekerja yang berdampak pada ketidakseimbangan antara asupan kalori dengan pengeluaran energi. Jika keadaan ini berlangsung terus menerus dan ditambah dengan aktivitas fisik yang kurang maka pekerja akan semakin berisiko untuk mengalami kelebihan berat badan dan obesitas. Sementara itu, untuk membentuk pegawai dengan produktivitas yang tinggi perusahaan juga harus bisa mendorongnya dengan baik. Oleh karena itu tujuan penelitian ini adalah untuk mengetahui derajat kebugaran jasmani para pegawai Pertamina Wilayah MOR IV Semarang dengan sebuah metode pelatihan guna menigkatkan status derajat kebugaran jasmani mereka melalui progam "BE FIT BYE FAT". Metode yang dimana akan menyokong dari aspek kesehatan para pegawai karena produktivitas suatu karyawan akan berdampak besar pada kemajuan perusahaan. Cara untuk meningkatkan produktivitasnya tersebut adalah bisa dengan melakukan metode pelatihan olahraga dimana metode tersebut berisi tentang penyuluhan dan peningkatan pemahaman pola makan hidup sehat, diet yang baik serta pemberian treatment olahraga, serta kepercayaan diri yang dimiliki oleh pegawai terutama dalam hal meningkatkan kinerja pelayanan. Dengan demikian diharapkan melahirkan suatu komitmen pencapaian misi pelayanan prima.

\section{Metode Penelitian}

Pelaksanaan penelitian bertempat di Pertamina MOR IV DAOP Semarang. Pengambilan data primer melalui tes pengukuran Indeks Masa Tubuh dan kebugaran jasmani meliputi jenis kelamin, usia \& status BMI. Penelitian ini menggunakan rancangan penelitian pretest posttest experiment dengan jumlah partisipan 44 orang. Sebelum melakukan penelitian peneliti terlebih dahulu menjelaskan prosedur penelitian kepada responden dengan melakukan sosialisasi dan pemahaman terkait pola makan hidup sehat, diet yang benar serta pentingnya berolahraga. Metode ceramah dilakukan dengan memberikan arahan materi kepada responden kemudian peneliti melakukan tes awal terkait pengukuran Indeks Massa Tubuh dan kebugaran jasmani meliputi push up, sit up dan Tecumseh test step. Metode yang digunakan sangat baik untuk memprediksi ketahanan kardiopulmoner dengan mengukur detak jantung sebagai respons terhadap langkah dan detak jantung pemulihan setelah latihan (Prasetyo, 2015). Selanjutnya dilakukan pendampingan latihan olahraga ini dilaksankan selama 4 bulan dari bulan April s/d Juli yang dilaksanakan seminggu 2x setiap hari Senin dan Rabu pukul 16.00 - 17.30 wib kepada para pegawai dengan jadwal untuk hari senin peserta ditekankan ke latihan cardio dengan treadmill atau sepeda statis selama 30 menit kemudian dilanjutkan latihan tabata dengan versi improvisasi dari olahraga High Intesity Interval Training (HIIT) untuk meningkatkan kebugaran dan performa olahraga yang biasanya menggabungkan berbagai latihan kardio, latihan kekuatan dan sebagainya dalam satu waktu. Untuk hari Rabu peserta dilatih dengan menekankan kardio dan strength. Latihan kardio sama dengan hari senin yaitu melakukan treadmill atau sepeda statis selama 30 menit dilanjutkan dengan latihan strength yaitu dengan latihan weight training ataupun latihan core stability. Model latihan weight training sangat berpengaruh terhadap penurunan body fat, adanya interaksi antara model latihan dan tingkat motivasi latihan terhadap penurunan body fat, model latihan Circuit weight training lebih baik. Setelah 4x pertemuan beban mereka naik $10 \%$ per itemnya. Adapun latihan weight training yang dilakukan antara lain: leg press, bench press, military press, seated row, lateral pull down, triceps, biceps, sit up, back. up. Sedangkan untuk latihan core stability ada 20 gerakan yang dilakukan dengan per item gerakan berdurasi 25-30 detik dan kemudian dilakukan tes akhir terkait pengukuran indeks masa tubuh dan kebugaran jasmani meliputi tes pengukuran Indeks Massa Tubuh (IMT), kebugaran dan kekuatan fisik untuk mengetahui status derajat kebugaran pegawai Pertamina MOR IV DAOP Semarang.

Instrumen yang digunakan untuk mengumpulkan data penelitian eksperimen ini berupa tes (pretest dan posttest). Menurut Sudjana (2011) analisis dengan metode eksperimen adalah metode yang mengungkapkan hubungan dua variabel atau lebih dan mencari pengaruh antara variabel yang satu dengan variabel yang lainnya. Dalam penelitian ini, penulis menggunakan pendekatan kuantitatif dengan penelitian eksperimen, dimana suatu hal dapat diteliti adanya pengaruh atau tidak dalam penelitian tersebut. Metode penelitian eksperimen adalah metode penelitian kuantitatif. Metode 
penelitian eksperimen dapat diartikan sebagai metode penelitian yang digunakan untuk mencari pengaruh perlakuan tertentu terhadap yang lain dalah kondisi yang dikendalikan (Sugiyono, 2017). Penelitian kuantitatif itu menelaah obyek dengan cara menghitung dengan menggunakan satuan angka untuk menetapkan ukuran obyek. Jenis penelitian yang digunakan dalam penelitian ini menggunakan tehnik analisis experimental design.

\section{Hasil}

Sajian data tes pengukuran ditampilkan dalam bentuk tabel dan diagram untuk mengetahui sebarapa besar jumlah distribusi frekuensi dari awal hingga akhir tes yang didapat dari sampel dalam penelitian ini. peneliti akan menyajikan analisa data berupa rata-rata dari populasi terhadap setiap variabel dengan menghasilkan diagram persentase.

. Tabel 1. Rekap Hasil Tes Pengukuran Data Total Kenaikan Persentase Tingkat Kekuatan dan Kebugaran Jasmani

\begin{tabular}{|c|c|c|c|c|c|c|}
\hline Karakteristik & Jumlah & Usia/thn & BMI & Push $U_{p}$ & Sit $U p$ & Back $U p$ \\
\hline $\begin{array}{l}\text { Jenis } \\
\text { Kelamin }\end{array}$ & Partisipan & $20-51+$ & $\begin{array}{l}\text { Overweight / } \\
\text { Normal }\end{array}$ & $(60 \mathrm{dtk} / \%)$ & $(60 \mathrm{dtk} / \%)$ & $(60 \mathrm{dtk} / \%)$ \\
\hline $\mathrm{L}$ & 11 & $20-29$ & Overweight & $18,52 \%$ & $21,83 \%$ & $10,07 \%$ \\
\hline $\mathrm{P}$ & 9 & - & Normal & $30,80 \%$ & $45,31 \%$ & $13,03 \%$ \\
\hline $\mathrm{L}$ & 6 & $30-39$ & Normal & $13,76 \%$ & $11,20 \%$ & $2,54 \%$ \\
\hline $\mathrm{P}$ & 7 & - & Normal & $13,26 \%$ & $32,82 \%$ & $1,08 \%$ \\
\hline $\mathrm{L}$ & 8 & $40-49$ & Normal & $17,50 \%$ & $10,33 \%$ & $5,42 \%$ \\
\hline $\mathrm{P}$ & 1 & - & Overweight & $24,32 \%$ & $27,08 \%$ & $-14,29 \%$ \\
\hline $\mathrm{L}$ & 1 & $50+$ & Overweight & $30,00 \%$ & $45,71 \%$ & $4,17 \%$ \\
\hline $\mathrm{P}$ & 1 & - & Overweight & $35,00 \%$ & $30,00 \%$ & $-12,70 \%$ \\
\hline
\end{tabular}

Berdasarkan data sajian tabel 1 di atas menunjukkan rekapan hasil rata-rata pada tes pengukuran awalakhir mengenai, karakteristik, usia serta BMI terhadap variabel dalam rata-rata. data sajian tabel diatas menunjukkan rekapan hasil rata-rata pada tes pengukuran pada pegawai dengan karakteristik (L) berjumlah 11 partisipan dengan usia 20-29 tahun dengan kategori status BMI overweight mempunyai rata-rata uji variabel dalam 60 detik : push up (18,52\%), sit up (21,83\%) dan back up (10,07\%). Sedangkan karakteristik (P) berjumlah 9 partisipan pada usia 20-29 tahun dengan kategori status BMI normal mempunyai rata-rata uji variabel : Push up (30,80\%), Sit Up (45,31\%), dan Back Up (13,03\%).

Pada karakteristik (L) berjumlah 6 partisipan dengan usia 30-39 tahun kategori status BMI normal mempunyai rata-rata uji variabel/60 detik: push up (13,76\%), sit up $(11,20 \%)$, back up (2,54\%). sedangkan karakteristik (P) berjumlah 7 partisipan pada usia 30-39 tahun dengan kategori status BMI normal mempunyai rata-rata uji variabel/60dtk : push up (13,26\%), sit up $(32,82 \%)$, back up $(1,08 \%)$.

Pada karakteristik (L) berjumlah 8 partisipan dengan usia 40-49 tahun kategori status BMI normal mempunyai rata-rata uji variabel/60 detik: push up (17,50\%), sit up $(10,33 \%)$, back up $(5,42 \%)$. Sedangkan karakteristik (P) berjumlah 1 partisipan pada usia 40-49 tahun dengan kategori status BMI overweight mempunyai rata-rata uji variabel push up $(24,32 \%)$, sit up $(27,08 \%)$, dan back up $(-14,29 \%$.).

Pada karakteristik (L) berjumlah 1 partisipan dengan usia 50+ tahun kategori status BMI overweight mempunyai rata-rata uji variabel/60 detik: push up (30,00\%), sit up (45,71\%), back up (4,17\%). Sedangkan karakteristik (P) berjumlah 1 partisipan pada usia 40-49 tahun dengan kategori status BMI overweight mempunyai rata-rata uji variabel: push up (35,00\%), sit up (30,00\%), dan back up $(-12,70 \%$.). 
Berdasarkan kesimpulan data sajian tabel 1 di atas maka_pada usia 20-29 tahun dengan karakteristik (L) total dengan jumlah 20 partisipan mempunyai rata-rata persentase total kenaikan $(50,42 \%)$ dan karakteristik $(\mathrm{P})$ mempunyai rata-rata persentase kenaikan ( 89,14\%). Pada usia 30-39 tahun dengan karakteristik (L) total berjumlah 13 partisipan mempunyai rata-rata persentase total kenaikan (41,35\%), dan karakteristik (P) mempunyai rata-rata persentase kenaikan (47,16\%). Pada usia 40-49 tahun dengan karakteristik (L) total berjumlah 9 partisipan rata-rata persentase total kenaikan $(33,24 \%)$, dan karakteristik $(\mathrm{P})$ mempunyai rata-rata persentase kenaikan (37,12\%). Pada usia 40-49 tahun dengan karakteristik (L) total berjumlah 2 partisipan mempunyai rata-rata persentase total kenaikan $(79,88 \%)$, dan karakteristik (P) mempunyai rata-rata persentase kenaikan (52,30\%).

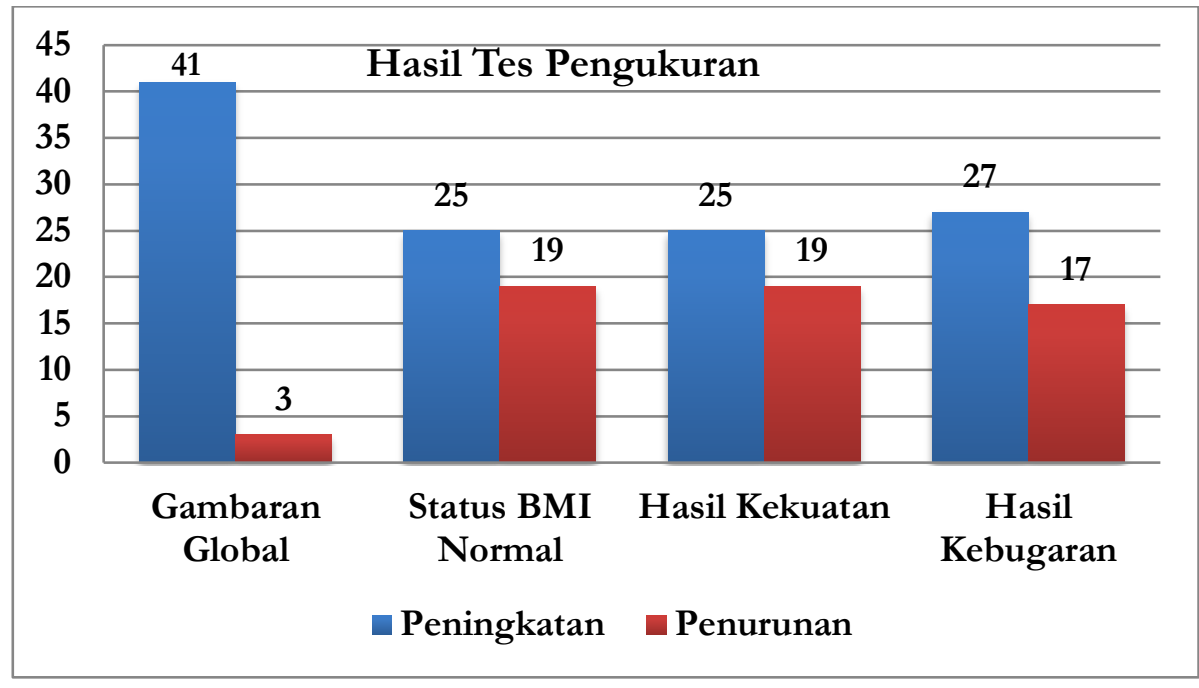

Gambar 1. Hasil Tes Pengukuran Total

Gambar 1 merupakan hasil tes pengukuran total dari data gambaran keseluruhan, status BMI normal, hasil tingkat kekuatan, hasil tingkat kebugaran yang menyebutkan bahwa pegawai yang mengalami kenaikan kebugaran sejumlah 27 pegawai $(61,36 \%)$ sedangkan yang tidak mengalami kenaikan kebugaran sejumlah 17 pegawai $(38,64 \%)$.

Berdasarkan kesimpulan gambar 1, hasil data tes pengukuran terhadap data gambaran keseluruhan, status BMI normal, hasil tingkat kekuatan, hasil tingkat kebugaran. Data tes pengukuran menunjukkan jumlah pegawai yang mengikuti program mengalami kenaikan sejumlah 41 pegawai $(93,18 \%)$ sedangkan yang tidak mengalami peningkatan sejumlah 3 pegawai $(6,82 \%)$. dari hasil status BMI normal dengan jumlah 25 pegawai (56,82\%) sedangkan yang berstatus overweight ada 19 pegawai (43,18 \%). Dari hasil kekuatan yang melebihi kenaikan lebih dari $20 \%$ sejumlah 25 pegawai $(56,82 \%)$ dan yang belum sampai mencapai kenaikan $20 \%$ sejumlah 19 pegawai $(43,18 \%$ ). Dari hasil kebugaran dapat diperoleh bahwa pegawai yang mengalami kenaikan kebugaran sejumlah 27 pegawai $(61,36 \%)$ sedangkan yang tidak mengalami kenaikan sejumlah 17 pegawai $(38,64 \%)$.

\section{Pembahasan}

Berdasarkan hasil tes pengukuran yang dilakukan secara global maka dapat diketahui bahwa masih terdapat pegawai Pertamina MOR IV Semarang yang mengalami overweight dan obesitas, kebanyakan dialami oleh pegawai dengan usia muda antara 20 - 29 Tahun. Berdasarkan hasil tersebut dapat disimpulkan bahwa program be fit bye fat yang dilakukan dapat menurunkan berat badan yang semula berstatus overweight. Namun sisanya adalah usia $38-50$ tahun yang masih belum mengalami penurunan berat badan. Menurut penelitian Miko \& Pratiwi (2017) disebutkan bahwa obesitas merupakan salah satu penyebab dari pola makan yang kurang baik maupun rendahnya aktivitas fisik. Namun dalam penelitiannya menyebutkan bahwa rendahnya kesadaran dalam mempertahankan pola makan dan 
aktivitaslah yang mempengaruhi keseimbangan kesehatan. Oleh karena itu Pegawai Pertamina MOR IV Semarang harus konsisten dalam melakukan latihan olahraga yang di berikan sebagai salah satu metode untuk menurunkan berat badan. Penelitian terdahulu menyebutkan bahwa terdapat hubungan bsermakna antara aktivitas fisik dengan stres usia pada fenomena obesitas, semakin berat akktivitas fisik, maka semakin rendah pula risiko obesitas, semakin berat stres maka semakin tinggi risiko obesitas, semakin tua usia maka semakin tinggi risiko obesitas (Sudargo et al., 2014). Penelitian lain menyatakan bahwa adanya hubungan antara aktivitas fisik, konsumsi fastfood, menonton TV, dan penggunaan gadget terhadap status berat badan pada seseorang dan aktivitas fisik merupakan variabel yang paling berpengaruh terhadap status berat badan (Hamalding, Risna, \& Susanti, 2019). Hal ini menjadi himbauan agar lebih mempertimbangkan menu makan yang sesuai kebutuhan energi baik dan aktivitas fisik yang mampu menyeimbangkan kognisi tubuh. Latihan olahraga, terlepas dari penurunan berat badan, memberikan banyak manfaat kesehatan khususnya bagi individu yang kelebihan berat badan dan obesitas berisiko terkena penyakit. Adapun penelitian yang dilakukan oleh Swift et al (2014) menyebutkan bahwasannya menurunkan berat badan berdasarkan program aktivitas fisik dan menekankan bahwa banyak manfaat kesehatan terjadi tanpa kerugian adanya berat badan. Namun menurunkan berat badan harus berpartisipasi dalam aktivitas fisik dan pembatasan kalori untuk meningkatkan kemungkinan penurunan berat badan dengam melakukan sebuah progam. Dengan demikian harapannya progam ini dapat menjadi metode untuk individu menentukan kebutuhan aktivitas olahraga apa yang akan dilakukan guna meningkatkan dan memperbaiki kembali SDM pegawai untuk menunjang peforma kebugaran jasmani para pegawai Pertamina Wilayah MOR IV Semarang.

\section{Simpulan dan Rekomendasi}

Upaya meningkatkan kebugaran jasmani pegawai Pertamina MOR IV Semarang dapat dilakukan melalui program "Be Fit Bye Fat" guna mengetahui derajat kebugaran jasmani dan meningkatkan pengetahuan pengelolaan aktivitas fisik berolahraga dan pola makan sehat. Serta menekan angka obesitas dan overweight dengan treatment berupa progam latihan olahraga cardio, weight training dan core stability setiap seminggu 2x setiap hari Senin dan Rabu berdurasi satu setengah jam. Dari total keseluruhan sampel_jika dilihat dari status BMI terdapat 50\% yang mengalami penurunan berat dan dari gambaran umum $(93,18 \%)$ yang mengalami penurunan berat badan. Oleh karena itu peneliti merekomendasikan sebuah progam treatment "Be Fit Bye Fat" sebagai metode dalam menurunkan berat badan. Treatment tersebut merupakan rangkaian dari program be fit by fat untuk meningkatkan dan memperbaiki SDM pegawai Pertamina Wilayah MOR IV Semarang. Dengan konsistensi melakukan progam treatment tambahan atau di lakukan secara mandiri di rumah setelah pulang kerja agar maksimal, sehingga menjadi budaya hidup sehari-hari serta meningkatkan kemandirian berperilaku hidup sehat dalam melakukan olahraga yang baik, benar, terukur dan teratur.

\section{Daftar Pustaka:}

Ade Chintya Nirmala Dewi, T. M. (2013). HUBUNGAN POLA MAKAN, AKTIVITAS FISIK, SIKAP, DAN PENGETAHUAN TENTANG OBESITAS DENGAN STATUS GIZI PEGAWAI NEGERI SIPIL DI KANTOR DINAS KESEHATAN PROVINSI JAWA TIMUR. Experimental Cell Research, 9(1), 42-48. https://doi.org/10.1016/0014-4827(56)90196-3

Alfianto Candra, Tavip Dwi Wahyuni, A. S. (2016). Hubungan Pola Makan Dan Aktivitas Fisik Terhadap Obesitas Pada Remaja Di Sma Negeri 5 Pekanbaru. Kesehatan Masyarakat, 3(I), 1-20.

Christina, D., \& Sartika, R. A. D. (2011). Obesitas pada Pekerja Minyak dan Gas. Kesmas: National Public Health Journal, 6(3), 104. https://doi.org/10.21109/kesmas.v6i3.100

Dodik, nida dan. (2015). Pengetahuan, Persepsi, Dan Penerapan Diet Penurunan Berat Badan. Journal 


\section{of Nutrition and Food.}

Hamalding, H., Risna, R., \& Susanti, S. R. (2019). Hubungan Gaya Hidup Terhadap Overweight Dan Obesitas Pada Remaja Putri Di Sma Negeri 11 Makassar. Jurnal Komunitas Kesebatan Masyarakat, 1(1), 1-6. https://doi.org/10.36090/jkkm.v1i1.240

Indonesia Sport Nutritionist Association. (2018). MET (Metabolic Equivalen).

Kusmawati, W., Lufthansa, L., Sari, R. S., \& Windriyani, S. M. (2019). BUKU AJAR ILMU GIZI OLAHRAGA. Uwais Inspirasi Indonesia.

Mappaompo, M. A. (2010). Obesitas Dan Olahraga. Jurnal Ilara.

Miko, A., \& Pratiwi, M. (2017). Hubungan Pola Makan dan Aktivitas Fisik Dengan Kejadian Obesitas Mahasiswa Politeknik Kesehatan Kemenkes Aceh (Relationship to Eating Pattern and Physical Activity with Obesity in Health Polytechnic Student Ministry of Health in Aceh). Hubungan Pola Makan Dan Aktifitas Fisik... 1 AcTion Journal, 2(1), 1-5.

Nurcahyo, fathan. (2011). KAITAN ANTARA OBESITAS DAN AKTIVITAS FISIK Oleh : Fathan Nurcahyo UnBi. Medikora, 7(1), 87-96.

Nursalam, \& Fallis, A. . (2013). Malnutrisi.

Pane, B. S. (2015). Peranan Olahraga Dalam Meningkatkan Kesehatan. Jurnal Pengabdian Kepada Masyarakat.

Prasetyo, Y. (2015). KESADARAN MASYARAKAT BEROLAHRAGA UNTUK PENINGKATAN KESEHATAN DAN PEMBANGUNAN NASIONAL. MEDIKORA. https://doi.org/10.21831/medikora.v11i2.2819

Puspitasari, N. (2018). FAKTOR KEJADIAN OBESITAS SENTRAL PADA USIA DEWASA. HIGELA JOURNAL OF PUBLIC HEALTH RESEARCH AND DEVELOPMENT, 2(2), 249-259.

Retnaningrum, G., \& Dieny, F. F. (2015). KUALITAS DIET DAN AKTIVITAS FISIK PADA REMAJA OBESITAS DAN NON OBESITAS. Journal of Nutrition College. https://doi.org/10.14710/jnc.v4i4.10150

RI Kementrian Kesehatan. (2018). Masalah Kesehatan Pada Lansia. Ditjen Yankes.

Sudargo, T., LM, H. F., Rosiyanti, F., \& Kusmayanti, N. A. (2014). Pola Makan dan Obesitas. In UGM PRESS.

Sudjana, N. (2011). Penilaian Hasil Proses Belajar Mengajar. Bandung: Remaja Rosdakarya.

Sugiyono. (2017). Penelitian Kuantitatif. Pemaparan Metodenpenelitian Kuantitatif.

Suryaputra, K., \& Nadhiroh, S. R. (2012). Perbedaan Pola Makan Dan Aktivitas Fisik Antara Remaja Obesitas Dengan Non Obesitas. Makara, Kesehatan, 16(1), 45-50.

Swift, D. L., Johannsen, N. M., Lavie, C. J., Earnest, C. P., \& Church, T. S. (2014). The role of exercise and physical activity in weight loss and maintenance. Progress in Cardiovascular Diseases. https://doi.org/10.1016/j.pcad.2013.09.012

Widiantini, W., \& Tafal, Z. (2014). Aktivitas Fisik, Stres, dan Obesitas pada Pegawai Negeri Sipil. Kesmas: National Public Health Journal. https://doi.org/10.21109/kesmas.v0i0.374 